Gimself again. A pint of beer would make him appear intoxicated, and he remained deaf on one side. He was given some light work to do on the line, and was struck and killed by an engine. It was found that there had been an extensive fracture of the petrous portion of the temporal bone. A considerable part of the fracture had been smoothly and firmly united. In other parts there were intervals There was $n$ o appearance of any ca'lns having been thrown ont. The preparation is in the causeam of the $R$ syal College of Surgeons of England.

CASE 7 -A private patient had long suffered from some irritation in pssing urine, and had an instrument introduced. After this he passed a small calculus, and on one side of this there was an accurate mou'd of the opening 3 of the spermatic ducts It was placed in the museum of st. George's Hos oital.

CASE 8 - In Norfolk one day I met a clergyman riding on hurseba :k. During our conversation his horse suddenly became restive, and jum ped ahout a good deal. Very soon after this $\mathrm{g}$-ntleman told me that a $\mathrm{sm}$ ill stone bad jassed from the urethra In this case, as in the last, the aloulas $d$ ubthess came from the prostate gland.

Queensborough-terrace, $\mathrm{W}$.

\section{REFLEX EPILEPSY.}

BY WILFRED J. HARRTS, M B.CANTAB., M.R.C.P.LoND. JUNIOR MEDICLL TUTOR, ST. MIRY'S HOSPITAL; LATE SENIOR HOUSE PHYSICIAY, NATIONAL GOSPITAL FOR THE PARALYSED AND

EPILEPTIC, QUEEN-SQUARE.

EPILEPTIC fits associated refloxly with some cuuse such as irritation of a scar, a diseased eyeball, or disease of the masal mucous membrane, hava oscasionally been met with. That is, such cases have developed an epileptogenous zone, analogous to Brown-Séquard's guinea pigs rendered epileptic by hemisection of the spinal cord, and in some cases removal of the peripheral suurce of irritation has been followed by cessation of the fits Dc. Hughlings Jackson ${ }^{1}$ is of opinion that every patient subject to fits has an epileptogenous $\mathrm{z}$ )ne, that in every epileptic patient there is a "discharging lesion " somewhere in the brain, and that disturbance of the part of the periphery (cutaneous, visceral, \&3.) most especially represented in this discharging lesion may provoke. a fit. Sir W. Gowers ${ }^{2}$ on the other hand, states: "It is excessively rare for cutaneous irritation to excite a fit. Epileptogenic zones, analogous to those of Brown-Séquard's guineapigs are practically unkno wn." Two cases have hitherto been recorded of epileptic fit following a touch on the head-one by Dr. James Dansmure ${ }^{3}$ in 1874 , and one by Dr. Hughlings Jackson ${ }^{4}$ in 1887. Both these cases were in boys, and in each thera was partial hemiplegia, more marked after the attacks. In the older case there was slight right hemi. plegia, with temporary right-sided paralysis after the attacks. In Dr Jackson's case the weakness was left-sided. In both fits were prodncible during sleep, and also tonching any part of the head in eicher case, if the patient were maware that he was going to be touched, produced a sudden iall or fit lasting a few seconds. Dr. Dunsmure's case was watched for eignteen years, the falls becoming less frequent after the onset of severe epileptic fils, and improvement was marked during the administration of bromides, as in Dr. Jackson's patient In each case the attack began at the age of two and a half years, but the attacks, being so short in duration, momentary falls only, loss of consciousness daring them could only be surmised, though it was probable. Dhrough the kindness of Dr. Jackson I am enabled to give the details of another somewhat similar case which wa zader his care at the National Hospital for the Paralysed and Epileptic recently, though in this case there were never any uuilateral symptoms or hemiplegia, nor were any fits erer produced daring sleep.

A girl, aged fire and a half years, was admitted to the dational Hospital for the Paralysed and Epileptic on Nor. 10;h, 1896 She was a seren-months' chilu', the labour baring been natural, and no instruments used. The father

Transactions of the Mediral Society of London, vol. x., 1887. Manual of Diseases of the Nervous System, p. 742

:Edinburgh Medical Jourual, October, 1874; alsj quoted by $\mathrm{Dr}$ Hughliags dackson in ThE LaYceT, Feb. 2nd, 1895. 4 Loc. cit. was stated to have suffered from syphilis before his marriage. There were tbree otber younger children, all healthy, with no history of epilepsy in the family. The patient had not had chorea, rheumatism, or scarlet fever. When three years old she had a series of convulsions during one morning, but bad no further attacks until nine months previous to admission. One month before this attack she bad a fall, striking the back of ber head, and she was dazed for some time afterwards, though whether the fall was due to a fit could not be ascertained for certain. A month later she began to fall about especially in the morning, and at first always fell on the back of ber head, though later she always fell forwards. Her parents said that the fits were always slight and momentary; her eyes turned up and the face sometimes twitched and she suddenly fell down, of ten striking her head or biting her lip. She had these attacks sometimes once only, sometimes a dozen during the day. After she had suffered from them for between two and three months her mother noticed that the fits were induced by touching her on the head, as by putting the hand on her forebead, or when smoothing back her hair, or in putting no her hat. If she was expecting a touch, no fit followed. $\mathrm{O} a$ the day of ber admission the nurse, in going to her to take off her hat, accidentally touched her head, and the child immediately fell forwards, the father remarking that that was what frequently happened. The same day, when her left cheek was suddenly touched without her expecting it she in mediately fell forward, her eyes rolled up, and she foamed at the mouth, there being definite transient loss of consciousness, followed by crying. There was no weakness of any limb nor any sign of hemiplegia, and at no time were there any one-sided symptoms, as in both the previously recorded cases. The knee-jerks were normal and there was no allection of sensation. The eyes were normal and there was no affection of any cranial nerve. She was a quick, nervous child, but of uncertain temper, and her intelligence was probably below the normal. She was under observation in the hospital until March 7th of this year, and during her four months' stay she had numerous fits, only occasionally a day passing without one, though she was taking six grains of bromide of potassium three times daily during the whole time. All the fits except two were of nearly the same character, often occurring when she was sitting up in bed, and she would fall with some violence against the iron bedrail, giving herself a black eye, or sometimes biting her lower lip, and generally crying afterwards, even if not burt. The nurse noticed several fits induced by smoothing back her hair, and after her admission three sudden fits, momentary falls, followed by crying, were produced during the first month by suddenly tapping her on the head without her knowing the touch was coming. Touching her during her sleep never produced a fit or any sudden change of colour or alteration in respiration, as in the two cases referred to above. During the latter half of her stay in hospital no fit could be induced by sudden touches, the child seeming to become accustomed to the not infrequent testing, and the spontaneous fits were also slightly less numerous. Only two severe fits were seen, with general convulsion and cyanosis, one a fortnight after admission, and another ten weeks later. It is noteworthy that about this time the $r \in f l e x$ fits produced by sudden touches ceased; and in D c. Dunsmure's patient it was noticed that the sudden falls became less numerous when ordinary epileptic fits supervened.

Craven-terrace, $w$.

\section{A CASE OF CARBOLIC POISONING FROM THE APPLICATION OF A CARBOLIC COMPRESS TO THE SKIN.}

BY R. CLEMENT LUCAS, B.S. LOND., F.R.C.S. ENG., SURGEON TO, AND LECTURER ON ANATOMYY AT, GUY'S HOSPITAL.

IN The LANCET of June 1st, 1895, I published, in conjunction with my colleague, Mr. Lane, two cases of severe carbolic poisoning caused by the absorption of the poison through the skin when applied for the purpose of disinfecting the skin previously to operation. The principal symptoms were those of collapse and coma, lasting several hours; but, severe as the symptoms were, both recovered. Since that 